\title{
The Grunge Inferno: Dante as read by Kurt Cobain
}

\author{
Giulio Carlo Pantalei \\ Università Roma 3 \\ giuliopantalei@gmail.com \\ https://orcid.org/0000-0002-5105-2527
}

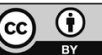

\begin{abstract}
This essay seeks to investigate the peculiar and undoubtedly intense relationship between Dante's Inferno and Kurt Cobain, lead songwriter to Grunge arguably most famous band, Nirvana, and main spokesman of the so-called "Generation X" at the beginning of the 90 in the Western Culture. Clues leading to Dantess first Cantica could be surprisingly found within all the records published by Nirvana, from Bleach (1989) to In Utero (1993), revealing an interesting cross section about the interpretation and the adaptation of Danters imaginarium in the United States and both a definitely enhanced picture of Kurt Cobain's artistic legacy and an exploration of the reading of the poem by the Western youth at the end of the last Century. Precise and fatal references to the XIIIth Canto concludes the survey, donating all the human depth beyond this intersection between Grunge era and Italian Middle Ages.
\end{abstract}

Key Words: Dante; Inferno; Kurt Cobain; Grunge; Nirvana; XIII ${ }^{\text {th }}$ Canto.

\section{Riassunto}

Questo saggio cerca di indagare il particolare e indubbiamente intenso rapporto tra l'Inferno di Dante e Kurt Cobain, cantautore di Grunge, probabilmente il gruppo più famoso, i Nirvana, e portavoce principale della cosiddetta "Generation X" all'inizio degli anni ' 90 nella cultura occidentale. Gli indizi che conducono alla prima Cantica di Dante potrebbero essere sorprendentemente trovati in tutti i dischi pubblicati dai Nirvana, da Bleach (1989) a In Utero (1993), rivelando un'interessante sezione trasversale sull'interpretazione e l'adattamento dell'immaginario dantesco negli Stati Uniti e sia un quadro decisamente migliorato dell'eredità artistica di Kurt Cobain, sia un'esplorazione della lettura della poesia da parte dei giovani occidentali alla fine del secolo scorso. Precisi e fatali riferimenti al XIII Canto concludono l'indagine, donando tutta la profondità umana al di là di questa intersezione tra l'era Grunge e il Medioevo italiano.

Parole chiave: Dante; Inferno; Kurt Cobain; Grunge; Nirvana; Canto XIII. 


\section{THE LITERARY SHELTER: A SUI GENERIS CULTURAL EDUCATION}

D ante's Inferno was one of Kurt Cobain's favourite books and he managed to hide footprints that lead to the Divine Comedy behind all of the three albums that Nirvana published, Bleach (1989), Nevermind (I99I) and In Utero (I993). These could sound as flamboyant catch phrases, but on the contrary it is the proper and, of course, quite surprising truth.

As a matter of fact, Grunge, arguably the most relevant American music phenomenon within the last decade of the 2oth Century, expression and sublimation of what was commonly named as the "Generation X" after a book by Douglas Coupland, held in its deepest roots unexpected literary references and it could be definitely interesting to point out that even before the widely-known literary infatuation of Eddie Vedder, Chris Cornell, Mark Lanegan, or Greg Dulli, the most celebrated artist within that creative movement had already paved the way to walk down that inner route along which offbeat literature becomes life and offbeat life becomes literature.

Sometimes the sleep of American small-towns produces geniuses and Kurt Cobain, born in 1967 in Aberdeen, Washington, definitely reacted through Rock and Roll and especially Punk music to a very difficult family situation, that forced him to live in dire straits and to face recurring episodes of bullying that eventually led him to give up his studies at the age of 17 (Cross 2008). Apparently, nothing could be further from the Italian Middle Ages and its poetic legacy, but it is exactly during this undeniably tough adolescence that Cobain started to attend a crucial place for his cultural upbringing, "where he spent many hours, often when he should have been in school" (Gaar 2009, 245) and where he met the work of Dante Alighieri. This period of homelessness, indeed, was frequently filled up with whole days reading books at the Aberdeen Timberland Library, a peculiar coincidence that brings to the memory the biographies of authors such as Henry Miller, Sandro Penna, or George Orwell in his Down and out in Paris and London, for instance. Like the ones just mentioned, the young musician found a real shelter in his local library, discovering the works and references that marked his future career the most. In his own words, drawn by a rare interview about his troubled boyhood, he said:

I toured the houses of all. After a couple of months I was not the most welcome ... and I was in misery. I often slept under a bridge and was also one of winters most ..., coldest weather memories. A freezing cold. I remember that walking all day without a goal, and I always ended up in the library. I spent there so much time, sitting and reading all the time, waiting for the end of the day. I was proud of me to be able to survive without a job. (Cobain qtd. in Schnack 2007) 
On the shelves of the library Kurt Cobain was introduced to the works of writers that ranges from American poetess Alicia Ostriker and the German novelist Patrick Süskind, whose best-selling book Perfume: the Story of a Murderer published in 1985 became the main inspiration for a well-known Nirvana song called Scentless Apprentice (1993), to the most influential countercultural author within the Beat Generation, that is William S. Burroughs, that became a real hero for the young artist, who tried in many occasions to get in touch with the creator of Naked Lunch in time and to set up an artistic fellowship with him, culminated in a 1993 experimental mix of spoken poetry and free noise improvisation called The "Priest" They Called Him. Later on in that same year, Cobain - that never had the chance to meet Burroughs personally - proposed him to be the main character for the brand new promotional Nirvana video for the song Heart-Shaped Box, written and treated by Cobain himself, and then he asked the writer to spend an afternoon together to talk about poetry, new projects and American cultural underground scene (Bertozzi 20I2; Rocha 20I4; Farnè 20I4). The writer declined the offer to impersonate the Pope on the Heart-Shaped Box music video, but it would be clear onward why this video is so important for the bond between Dante and Kurt Cobain.

\section{From the MUdDY BANKS OF THE INFERNO: Dante's Upper Hell drawn by Kurt Cobain}

There is proof that from the very first time he read it until the end of his too short but intense and passionate life, the young American artist never stopped admiring and celebrating the Italian poem. The first evidence dates back directly to Nirvana's debut album Bleach, released in 1989, for whose promotional tour Cobain himself - who was genuinely good at drawing since his childhood - decided to design original merchandise, some of that now exhibited at EMP/SFM Museum of Seattle. Surprisingly, one among the three $\mathrm{t}$-shirts created by Kurt depicts in the front a blow up of the Upper Hell as described and architected by the Florentine poet and it is possible to be ultimately sure about the literary source behind this operation thanks to the first run-up sketches contained in his Journals, that precisely reports "Rings of Dante's Hell" (Cobain 2003, I08). Widely-known photographic proof of this article of clothing are available on the Internet.

The back of the t-shirt, that could definitely appear as provocative and expressionist at first glance, allows us by contrast to understand what was associated to the reading of Dante's first Cantica in the imagination of the musician, aged 22 at that time, that is to consider himself and his circle of friends as damned souls. As a matter of fact, these are the sentences that stand 
up on the back-print: "FUDGE PACKIN / CRACK SMOKIN / SATAN WORSHIPPIN / MOTHER FUCKER”.

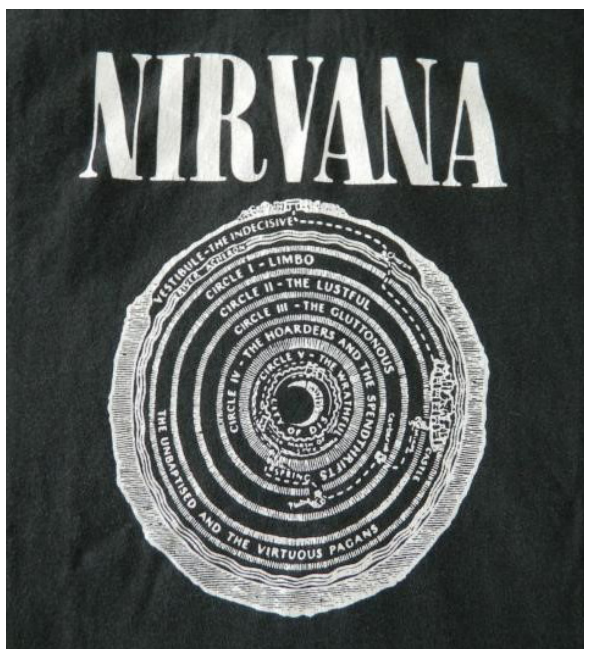

The vulgar, deranged and almost scatological attitude, typical of Punk music, holds at the same time the power to show that the most realistic aspects of the Commedia, certainly present in Dante's Inferno as the most deplorable and base instincts of men but for this very reason worthy of being represented with the function of admonition and with a literary mindset "sublime and all-encompassing" where "highest and lowest, wisdom and folly, abstract concept and concrete thing, feeling and event, all have their legitimate place in it" (Auerbach 1961, 97), possessed the inexhaustible potential to communicate with the youngest Western generations of the late $20^{\text {th }}$ Century, that tried to "escape from class" towards "a detachment from the constraints and anxieties of the whole class racket" (Fussell 1983, I87), feeling too often lost and abandoned.

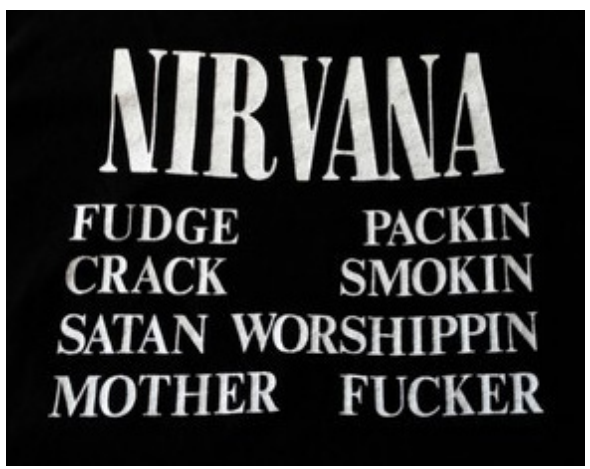




\section{With the lights out: the unexpected presence of Dante IN NiRVANA's NeVERMind}

The second attestation of Dante within an official record by Nirvana leads to their second critically and publicly acclaimed masterpiece, Nevermind, a work that defined a whole era for the Western youth at the beginning of the 9os, taking into consideration the fact that probably "no album in recent history had such an overpowering impact on a generation like this one" (Rolling Stone 20I2). On the back cover of the sleeve it appears a collage as bizarre as peculiar to decode, in which a toy monkey that pins a dead butterfly is put on the foreground and a combination of almost melted human figures (including glam-metal band Kiss) is juxtaposed on the background, enveloped one to each other. Asked about the meaning and the iconographic imaginarium behind quite a particular image, Cobain, taking the interviewer by surprise, explained that he had etched and mixed together some cuttings of illustrations drawing damned souls through the flames of Dante's Inferno:

The hellish background was made by Kurt when he was in his self-described 'Bohemian' photography stage, and for years it hung on his refrigerator door in Olympia. He explained [...]: "It's a collage I made many years ago. I got these pictures of beef from a supermarket poster, cut them out, and made a mountain of beef resembling the Inferno. And then I put Dante's people all over it." The collage featured not only pictures of beef and men and women burning in Dante's Inferno, but also "a picture of Kiss in the back standing on a slab of beef." (Cobain qtd. in Berkenstadt, Cross 1998)

Nobody has ever suggested an interpretation for such a distinctive visual choice to figure in the album, that on the contrary acquires in my opinion a certain significance, since - on closer inspection - it is somehow specular to the definitely more famous front cover; indeed, it may seem that the loss of innocence symbolized on the recto by a baby swimming underwater after a banknote hung on a hook could create a mirror-like estranging effect if matched with a toy from Cobain's childhood surrounded by flames, in order to create a vivid figurative connection between the watery, fluid, uterine front pole and its burning, scorching, and distorted opposite at the back.

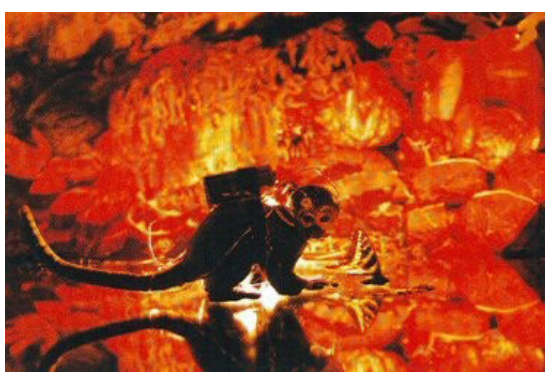


The frame of the references by now analysed walks along perfectly with the lyrics and the music in the record, of course, but, above all, it necessarily leads to some crucial questions in terms of literary success, destiny and tradition about its relationship with the Sommo Poeta: first of all, how is it possible that an American small-town boy without a proper education and of no fixed abode could enter so deeply the reading of a Medieval Italian poet? The answer gets back to the aforementioned 'homeless days' at Aberdeen Public Library, where Michael Azerrad was capable to retrace the attendance register related to the young Cobain. From the borrowers register it is definitely surprising to verify the regular presence of Dante, in the form of book, art catalogues and also movies, with the film adaptations both called Dante's Inferno respectively directed by Henry Otto in 1924 and by Harry Lachman in 1935 . The biographer, in a passage about the above-mentioned garment designed by Cobain, discloses: "On the front was a reproduction of an engraving of one of the circles of Hell from Dante's Inferno, a book Kurt had discovered and frequently read during his days passing the time in the Aberdeen Library" (Azerrad I993, II8). Sometimes, nevertheless, chance takes on the gloomy veinings of doom and the next clue along this Dantesque path brings straight to the hopeless last span of the artist.

\section{A Forest-Shaped Box: a son lost in the dark wood}

If the previous infernal references could sound as quite generic in relation to Dante's first Cantica, it is in the third and final Nirvana record, In Utero, that a more particular and meaningful clue can be found. Specifically, within the conception of Heart-Shaped Box, chosen as the first promotional single, Kurt Cobain moulds some definitely mysterious lyrics, which stands out for their substantial metaphorical and symbolistic tone:

She eyes me like a Pisces when I am weak

I've been locked inside your heart-shaped box for weeks

I've been drawn into your magnet tar pit trap

I wish I could eat your cancer when you turn black

Hey! Wait! I've got a new complaint

Forever in debt to your priceless advice

Psychological critics would certainly come across a rich soil upon which delving deeper into the inferences behind these lyrics, that could have been interpreted only after the printing of the musician's Journals. Leafing through the pages of the book, indeed, Cobain writes down as the main source behind the words for this song the "Camille's vaginal/flower bleeding theory" (Cobain 2003, 108) coined by the famous American intellectual Camille Paglia, who associated the female reproductive system to floral shapes and arrangements 
especially in a very artful chapter of her essay Sexual Personae dealing with the sexual implications of Sandro Botticelli's Birth of Venus and Primavera. Taking a closer look to these passages, the presence of Dante is inevitable:

Because of its enclosed space and atomized placement of figures, I classify the painting as decadent - the last gasp of Gothicism. The umbrella pine is Botticelli's favorite symbol of contracted omnipotent nature, overhanging human thought. In the Primavera the dark grove is an emanation of Spring's bulging womb, at the picture's exact center. Why do we not rejoice at the promise of fertility? We seem to be in elegy, not pastoral. The spindly trunks, ashy leaves, and metallic fruit belong to Dante. There is a sunless sky we cannot reach. The trees are a spiritual stockade. The figures are separated by invisible barriers. Each is locked in an allegorical cell, oblivious to the others. (Paglia 1990, 15I-2)

In the following verses the debt is even more evident:

Meat-eating orchids forgive no one just yet

Cut myself on angel's hair and baby's breath

Broken hymen of Your Highness I'm left black

Throw down your umbilical noose so I can climb right back

About the metaphor - topical within the Western Culture - which connects the female genitals to the flowers in their blooming, it was Tennesse Williams to put near each other in American modern Culture the vagina and the orchid, as pointed out by Paglia herself who quotes: «All I could see was something that looked as a dyin' meat-eating orchid» (Williams qtd. in Paglia, 434).

However, what mostly concerns our debate, strangely linking up Paglia's theory and the father of the Italian Literature, is related to the script notes that Cobain wrote on his diary as cutlines for the creation of the visual score for the song, that eventually became a seminal video written by Kurt Cobain himself and directed by Dutch avant-garde film-maker Anton Corbjin. The short film was also awarded the MTV Best Alternative Video in 1994 and the Time Magazine included it among "The thirty all-time best music videos" defining it as "a wise child's nightmare [...] It's beautiful and it's terrible" (Time 20II). The uncanny power of the work is located in an expressionistic overturning of some among the utmost good figures of the Western tradition: there is a Pope (or maybe even Jesus himself) but he is hospitalized on a deathbed, there is Santa but he is crucified and anorexic, there is a fair little girl but she is hooded and disguised as a Ku Klux Klan affiliate, dark plastic crows reverse the white doves of the Holy Spirit. In this monstrous scenery, the band plays in front of a very peculiar background which faithfully follows the Forest of the Suicides depicted by Dante in the XIII Canto of the Inferno.

Indeed, among the last pages of Cobain's Journals, Dante is mentioned more than once and always referring to the trees made of "words and blood" 
that populates the poet's fantasy regarding the self-murderers. Browsing among the sketches and the notes, it gets clear that the poetic fascination goes back to the original draft of the writing and, yet in the first paragraphs dedicated to the concept of In Utero, the songwriter noticed:

Ask about Dante's Inferno canto XIII movie from the 30 s to use instead of making our own props we will use the scenes of people entwined in old withering oak trees (Cobain, 228)

Again, with similar words, an annotation for the above-mentioned script included within his daily diary entries:

Animation. A forest. Dante's Inferno from the thirties

Dante canto XIII

Bodies entwined in old oak trees

Maybe we can use the original

footage from that movie of canto XIII (Cobain, 226)

In the end, the footage from the original movie weren't used but Cobain's will - definitely determined and quite philological - to play in front of that particular wood led to a faithful re-enactment of the horrific contrapasso imagined by the Florentine poet for the guilty of the crime of suicide, that is, as commonly known, being transformed into trees repeatedly tormented by the Harpies, as a punishment for having

uprooted themselves from their bodies (since) this unnatural separation, which in life is the work of a single moment of blind passion, and the wound which the suicide inflicts on himself, Dante renders eternal. The soul violently separated from the bodies ... remains enclosed in a body strange to it and of lower nature, in a plant that will feel every hour the violence which the suicide wrought on himself in life ... The hell of the suicides is suicide repeated every moment to eternity. (De Sanctis qtd. in Alighieri 1961, 176)

These frames in the following page show the final impressive result of Canto XIII's visual impact as modelled by the restless soul of Kurt Cobain. It could be particularly interesting to pay attention to the use of the colours, vividly sketched and accurate as compared to Dante's description.

In addition to this, Cobain decided to utilize those very scenic design as part of the stage props throughout the tour supporting their last record, quite a distinctive figure if considered that the band never adopted a proper live scenography during its career. This feature was later unveiled by the bass player

Krist Novoselic, probably unaware of the Dantesque motif that had inspired his bandmate: 
Following the release of In Utero in I993, we once again hit the road. Using left-over props from the "Heart Shaped Box" video shoot as set dressing (our first foray into the world of stage props), we concentrated on working up a set that spanned the band's entire career and gave the audience a longer show than we had done on past tours. (Novoselic qtd. in Nirvana 1996)
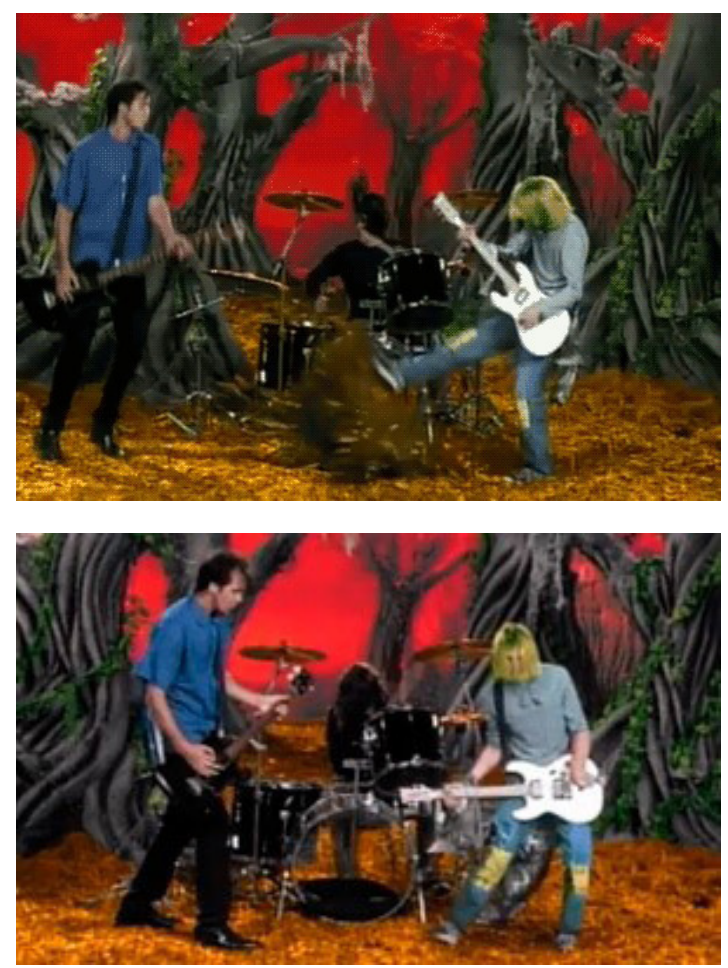

It seems clear that the inner meaning behind the choice of that particular backdrop didn't restrict to only a scenic purpose, but it rather carried a weight and a profound symbolic value in the songwriter's eyes, a value that inevitably brings to mind the extreme action that Cobain carried out on April $5^{\text {th }}$, 1994, as if to say - similarly to what happens in the video - that playing surrounded by those trees and that forest, metaphorically, was like getting closer, day by day, gig by gig, to that fatal wood.

For this reason, probably the one and only conclusion to this visceral human and literary path might dwell within the verses of Dante himself, alive among those who renounced to the living, at the entrance of the forest, where a blood-red sky lays darkly upon black withered branches: 
Io sentia d'ogne parte trarre guai e non vedea persona che 'l facesse; per ch'io tutto smarrito m'arrestai.

Cred'io ch'ei credette ch'io credesse da gente che per noi si nascondesse.

Però disse 'l maestro: "Se tu tronchi qualche fraschetta d'una d'este piante, li pensier c' hai si faran tutti monchi”.

Allor porsi la mano un poco avante e colsi un ramicel da un gran pruno; e 'l tronco suo gridò: "Perché mi schiante?".

Da che fatto fu poi di sangue bruno, ricominciò a dir: "Perché mi scerpi? non hai tu spirto di pietade alcuno? (Alighieri 1991, 366-9)

Since the pity and sympathy one could feel are way too deep, a final reflection upon this fragile matter that startlingly connects Nirvana to Dante Alighieri is definitely required.

\section{Don't ever fade away: Why Dante?}

It appears difficult and delicate to draw any conclusion about this hyperbolic intersection between such different and distant figures and works, a compound that could provoke a slight sense of estrangement in adiecto. Delving deeper into this relation, however, it is first reasonable to state that even though the refunctionalization of the Dantesque model could look as unsorted or unsystematic at first sight - the design for a t-shirt, an experimental collage and a scenography for a short film - it is also undisputable that a deep conceptual bond between Kurt Cobain and Dante somehow existed and was manifested more than once by the American songwriter. So, echoing a title from John A. Scott, perché Dante?

Probably the first answer to this question leads to the modernity and the inexhaustible fantastic imaginarium moulded by the Florentine poet, inclined to inspire and move readers from all over the world even after almost seven centuries from its publication and also within different artistic media, just as happened to Bob Dylan, whose work represented for all the American songwriters "a sort of Constitutio Antoniana for what concerns the relationship between music and literature in the Contemporary Age, having given free circulation and citizenship to the poetic Word, from the Classics to the Avant-garde, within the $20^{\text {th }}$ Century way of writing lyrics" (Pantalei 20I6, 20). Another point, naturally connected to the previous one, is an enhance- 
ment by Cobain of the goriest and most macabre passages of the Commedia, as if Dante had written only a Cantica: the rings of Dante's Inferno in the first case, the damned amassed through flames one on each other in the second, the eerie contrapasso for the suicides in the last. This definitely falls within both an expressionistic reading of the poem in step with the phenic-acid imaginarium of the first part of the gos in the US and an American typical tendency to focus on the Divine Comedy as a horror masterpiece, to such an extent that the widely-known video games company Commodore 64 and Electronic Arts published two different action video game adaptations called Dante's Inferno respectively in 1986 and 20I0, inspired by the canticle but having unquestionably very less to do, just to not say anything to do at all, with the literary value of the original work.

Nevertheless, if the two first tributes paid by Cobain to the Sommo Poeta could be placed on a same wavelength, the third one, that is the setting retracing the wood of the self-murderers from Inferno XIII, appears as different due to a more detailed research and reading of the book and, of course, a deeper human value. As a matter of fact, even if it should be a task for psychologists and specialists, it seems that the will to play his last songs in front of that scenery and the choice of that particular canto is in some way ultimately connected to the tragic death of the artist, that shot himself in the head some months later, at the age of 27 . If the dark wood was at this point way too long rooted within his soul and the Inferno had slowly turned into his personal life, his addiction and the showbusiness around him, his fondness for Dante was a true and attentive passion that, de facto, went with him throughout his whole career, from the days when he had no money to the day he became the spokesman of a whole generation with his songs. To conclude this visceral journey from Grunge to the Middle Ages, therefore, it would be hyperbolic and beautiful to create a junction between the final glimpse of the stars taken by Dante after his trip on the back of Lucifer and the suggestion of a young American artist of feeling as one with the sun. Like this, a little big Grunge revolution took place within the modern reception of the Commedia. 


\section{Works Cited}

Alighieri, D. (196I). The Divine Comedy of Dante Alighieri: the Inferno. ed. Allen Mandelbaum. Oxford: Oxford University Press.

Alighieri, D. (I991). La Divina Commedia. Inferno. ed. Anna Maria Chiavacci Leonardi. Milano: Mondadori.

Auerbach, E. (196I). Dante, poet of the secular world. Chicago: University of Chicago Press.

Azerrad, M. (1993). Come As You Are: the story of Nirvana. New York: Doubleday.

Bertozzi, C. (20I2, I3 ${ }^{\text {th }}$ January). "Quando Kurt Cobain scrisse a William Burroughs. Il carteggio inedito". Satisfiction.

Burroughs, W. S. (1993). and Cobain K. The "Priest" They Called Him. Tim/Kerr Records.

Cobain, K. (2003). Diari. Milano: Mondadori. (It ed. Journals. New York: Riverhead Books).

Cross, C. R. (200I). Heavier than Heaven: A biography of Kurt Cobain. New York: Hyperion.

Farné, E. (20I4). "Se Grunge e Beat Generation raggiungono il Nirvana: l'incontro tra Kurt Cobain e William Burroughs". Rai News.

Fussell, P. (1992). Class: A Guide Through the American Status System. New York: Simon and Schuster.

Gaar, G. G. (2009). The Rough Guide to Nirvana. London: Dorling Kindersley Ltd.

Kurt Cobain: About a Son. (2007). Dir. Schnack, AJ. Balcony Releasing. Min: 32:5033:03.

Nirvana. (1989). Bleach. Sub Pop.

Nirvana. (I99I). Nevermind. DCG Records.

Nirvana. (1993). In Utero. DCG Records.

Nirvana. (1996) From the Muddy Banks of the Wishkah. DCG Records.

Paglia, C. (1990). Sexual Personae: art and decadence from Nefertiti to Emily Dickinson. New York: Vintage Books.

Pantalei, G. C. (2016). Poesia in forma di Rock: letteratura italiana e musica angloamericana. Roma: Arcana.

Rocha, S. (20I4). Nada es verdad, todo està permitido. El día que Kurt Cobain conoció a William Burroughs. Barcelona: Alpha Decay.

Rolling Stone. "The 500 Greatest Albums of All Time. Nirvana: Nevermind." < https:// www.rollingstone.com/music/music-lists/500-greatest-albums-of-all-time-I56826/ nirvana-nevermind-50643/ >. Last accessed January I6, 2019.

Time Magazine. "The 30 ALL-TIME Best Music Videos." < http://entertainment. time.com/20II/o7/28/the-30-all-time-best-music-videos/slide/nirvana-heartshaped-box-I993/ >. Last accessed January I6, 2019. 